\title{
P̈̈̈KKIRJOITUS
}

\section{KOULUTUKSEN ARVIOINTI UUSIKSI}

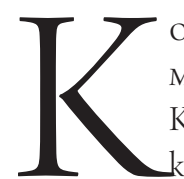

OULUTUKSEN ARVIOINTIJÄRJESTELMÄ pantiin uusiksi 1. toukokuuta 2014. Koulutuksen arviointineuvosto, Korkeahallituksen arviointiyksikon toim ja tilalle perustettiin Kansallisen koulutuksen arviointikeskus. Aiemmin kolmen organisaation voimin harjoitettu arviointitoiminta tuhlasi voimavaroja eikä kyennyt järkiperäiseen yhteistyöhön.

Koulutuksen arviointineuvosto joutui kymmenvuotisen toimintansa aikana hakemaan paikkaansa yhtäällä arvioinnin kentällä ja toisaalla suhteessa hallintoon. Opetushallituksen ja Koulutuksen arviointineuvoston yhteistyö ei saanut millään tolkullisia muotoja. Suhteet olivat alusta lähtien huonot ja toimimattomat. Vuonna 2003 toimintansa aloittanut Koulutuksen arviointineuvosto nimittäin perustettiin pääosin Opetushallituksen aiemmalle tontille. Opetushallitus oli menettänyt uskottavuuden riippumattomana arviointitoimijana, ja eduskunta halusi perustaa arviointia varten hallinnon ulkopuolella toimivan riippumattoman ja uskottavan asiantuntijaelimen. Opetushallitus piti kuitenkin kynsin hampain kiinni arviointitoiminnastaan, ja vuoden 2008 lainsäädännössä sen tehtäviin määriteltiin oppimistulosten arvioinnit.

Koulutuksen arvioinnin kokonaisuuden kannalta Koulutuksen arviointineuvoston perustamislainsäädäntöön jäi alun perin valuvikoja. Moninapainen arviointijärjestelmä hukkasi resursseja ja aiheutti epä- tietoisuutta ja sekaannusta. Oppimistulosten arvioinnin jääminen pois Koulutuksen arviointineuvoston tehtävistä heikensi olennaisesti koko ulkoisen arviointitoiminnan vaikuttavuutta. Kansallisen koulutuksen arviointikeskuksen aloittaessa koulutuksen panoksia, edellytyksiä ja toimintaa koskevia tietoja päästään analysoimaan rinnan oppimistulosten kanssa, kun oppimistulosten arviointi ole enää eristettynä hallinnon sisälle.

VASTA NYT koko arviointitoiminta siirtyy hallinnon ulkopuolelle, mikä on riippumattoman arviointitoiminnan keskeinen kriteeri. Toinen tärkeä muutos on pääseminen irti arviointitoimintojen hajanaisuudesta: entinen järjestelmä ei suonut käytännön edellytyksiä koulutussektorien rajat ylittävälle yhteistoiminnalle. Tämä on tärkeää erityisesti aikuiskoulutuksen arvioinnin kannalta. Koulutusjärjestelmän kehittäminen kokonaisuutena edellyttää päätöksenteon tueksi koulutussektorit ja -asteet ylittävää arviointitietoa, minkä uusi arviointikeskus tekee nyt mahdolliseksi. Se, että uuden lainsäädännön mukaan arviointineuvosto laatii esityksen arviointisuunnitelmaksi, jonka opetus- ja kulttuuriministeriö hyväksyy, turvaa niin ikään arvioinnin riippumattomuutta. Aiemmin arviointisuunnitelman laati opetusministeriö, mikä vei Koulutuksen arviointineuvostolta pois huomattavan osan arviointipoliittista valtaa ja rampautti neuvoston asiantuntemuksen mielekästä käyttöä. Ar- 


\section{ARVIOINTIÄHKYN LISÄ̈̈MISEN \\ SIJAAN TYÖNTEKIJÖIDEN PITÄISI}

ANTAA KESKITTYÄ TYÖNTEKOON.

vioitavat kohteet ja arviointien aikataulut sisältävän suunnitelman ansiosta arviointitoiminnan pitkäjänteisyys, systemaattisuus ja ennakoitavuus paranevat.

KANSALLISEN KOULUTUKSEN arviointikeskuksen tehtävänä on: (1) toteuttaa koulutukseen sekä opetuksen ja koulutuksen järjestäjien ja korkeakoulujen toimintaan liittyviä arviointeja valtakunnallisen arviointisuunnitelman mukaisesti; (2) tehdä perusopetuksen ja lukiokoulutuksen, ammatillisen koulutuksen ja ammatillisen aikuiskoulutuksen sekä taiteen perusopetuksen oppimistulosten arviointeja; (3) tukea opetuksen ja koulutuksen järjestäjiä sekä korkeakouluja arviointia ja laadunhallintaa koskevissa asioissa; (4) kehittää koulutuksen arviointia; sekä (5) huolehtia muista tehtävistä, jotka säädetään tai määrätään sen tehtäviksi.

Kansallisen koulutuksen arviointikeskuksen asiantuntijaelimenä toimivalta arviointineuvostolta on lupa odottaa malttia ja harkintaa arviointitoimintaan. Liialla arvioinnilla tapetaan luovuus ja luottamus. Se uhkaa työn iloa. Arviointi on vain väline koulutuksen kehittämisessä. Eikä kehittäminenkään ole itseisarvo. Työ- ja koulutusorganisaatioita on 1990-luvulta lähtien "kehitetty" niin taajaan, että henkilöstö väsyy jatkuviin muutoksiin. Arviointiähkyn lisäämisen sijaan työntekijöiden pitäisi saada keskittyä työntekoon. "Ei sika punniten liho", tietää kansanviisaus.

SUOMEN KOULUTUSJÄRJESTELMÄ on saanut runsaasti myönteistä huomiota maailmalla, kun peruskoululaisten ja nyt myös aikuisväestön taidot ja osaaminen on 2000-luvulla todettu OECD:n testeissä erinomai- siksi. Aikuisten luku-, numero- ja ongelmanratkaisutaitoja mittaavassa PIAAC-arvioinnissa Suomi sijoittui maiden välisessä vertailussa kakkostilalle. Viime syksynä julkistetussa PISA-vertailussa Suomen sijoitus aleni selvästi. Kyse ei ole ainoastaan siitä, että muiden maiden nuoret olisivat kehittyneet Suomen nuoria nopeammin, vaan siitä, että suomalaisnuorten keskimääräisen luku- ja matemaattiset taidot ovat yksinkertaisesti huonontuneet.

Maidenväliset ranking-listat saavat runsaasti huomiota. Esimerkiksi heikot PISA-tulokset ovat olleet joissakin maissa kansallinen shokki. PISA-arvioinnit ovat sysänneet liikkeelle koulutuspoliittisia uudistuksia, joiden seuraukset ovat voineet olla myös monin tavoin epätoivottavia. Tässä suhteessa arvioinnit eivät ole aivan viatonta toimintaa. Niillä on väistämättä poliittisia ulottuvuuksia, jopa poliittisia tarkoitusperiä.

Iso JOUkкo koulutustutkijoita julkaisi hiljattain brittiläisessä Guardianissa vetoomuksen PISA-testien lopettamiseksi niiden negatiivisten seurausten vuoksi. Allekirjoittajien joukossa oli tutkijoita ympäri maailmaa, esimerkiksi professorit Stephen J. Ball, Henry Giroux, David Labaree, Michael Peters, Peter McLaren, Sally Tomlinson.

Kasvatuksen ja koulutuksen tärkein tehtävä on jotain muuta kuin lasten ja nuorten valmentaminen testeihin. Kun koulutuspolitiikkaa aletaan tehdä arvioinneissa menestymisen vuoksi, nuoria kohdellaan pelkkinä pelinappuloina. Pitäisi kasvattaa sivistyneitä ja kriittisiä kansalaisia eikä testiviisaita.

Heikki Silvennoinen 